\title{
Isolation, Serotyping and In-vitro and In-vivo Antibacterial Sensitivity of Escherichia coli Strains Isolated from Diarrheic Lambs in Kashmir
}

\author{
N. Hassan* and G.N. Sheikh \\ Department of Veterinary Medicine, Faculty of Veterinary Sciences, \\ Sher-e-Kashmir University of Agricultural Sciences and Technology, Kashmir, \\ Shuhama Campus Srinagar- 190 006, J\&K, India \\ *Corresponding author
}

\begin{tabular}{|c|c|}
\hline & A B S T R A C T \\
\hline $\begin{array}{l}\text { Diarrhea, Lambs, } \\
\text { in-vitro, in-vivo, } \\
\text { Escherichia coli, } \\
\text { Serotypes, } \\
\text { Antibacterial } \\
\text { sensitivity. }\end{array}$ & \multirow{3}{*}{$\begin{array}{l}\text { This study was aimed to isolate the Escherichia coli strains and to compare the in-vitro and } \\
\text { in-vivo antibacterial sensitivity of Escherichia coli strains isolated from diarrheic lambs. } \\
\text { Different strains of Escherichia coli were isolated from the clinically affected lambs. } \\
\text { Principal serotypes of E. coli recovered were O20 (10.09\%), O11 ( } 8.25 \%) \text {, O123, O84 } \\
\text { and O22 (7.33\% each), O107 (5.50\%), O89 and O92 (3.66\% each), O69 and O5 (2.75\% } \\
\text { each), O157, O15, O36, O159 and O60 (1.83\% each). Serogroups O26, O23, O17, O157, } \\
\text { O153 and O5 with established zoonotic importance were among those recovered from } \\
\text { diarrhoeic lambs. The antimicrobial susceptibility pattern of the isolates showed isolates } \\
\text { were sensitive to four antibacterials, viz. gentamicin ( } 61.33 \%) \text {, ciprofloxacin (60\%), } \\
\text { neomycin (54.6\%) and co- trimoxazole (50.6\%). while as, the isolates were resistant to } \\
\text { amoxicillin and oxacillin. The therapeutic efficacy (in-vivo) of four highly effective } \\
\text { antibacterials were evaluated and treatment regimen used in four different groups of } \\
\text { clinical cases indicated, gentamicin and ciprofloxacin most effective drugs followed by } \\
\text { neomycin and co-trimoxazole which was comparable with their in-vitro efficacy. }\end{array}$} \\
\hline Article Info & \\
\hline $\begin{array}{l}\text { Accepted: } \\
\text { 20 January } 2017 \\
\text { Available Online: } \\
\text { 10 February } 2017\end{array}$ & \\
\hline
\end{tabular}

\section{Introduction}

Epidemiological studies on diarrhea in lambs, have shown that colibacillosis is one of the most important causes of neonatal lamb diarrhea that is followed by mortality and is responsible for 14-30 per cent of lamb deaths (Ahmed, 2009). The disease is caused by pathogenic serotypes of Escherichia coli (Gyles, 1992). Escherichia coli (E. coli), a member of family Enterobacteriaceae is a short Gram negative, non-spore forming motile bacillus. According to modified Kauffman scheme, the organism is serotyped on the basis of its somatic $(\mathrm{O})$, flagellar $(\mathrm{H})$ and capsular (K) surface antigens (Lior, 1996). The distribution of different serotypes of $E$. coli varies with the geographical regions and their prevalence in man and animals in a particular area. Over 700 antigenic types or serotypes of $E$. coli have been recognized based on these three antigens (Nataro and Kaper, 1998). The detection and accurate identification of $E$. coli is enormously important as the distribution of different serotypes and the prevalence in animals varies with the geographical regions (Hassan and Sheikh, 2013). Although antibiotics are 
frequently used for both treatment and prevention of $E$. coli scours in lambs and calves to minimize losses (Novotna et al., 2005) but in recent years, the emergence of drug resistant strains following extensive and indiscriminate use of antimicrobial agents for therapy and prophylaxis has led to loss of their efficacy (Schoenian, 2006). Resistance to almost all front line antimicrobials is demonstrated by $E$. coli isolates from lambs (Ahmed, 2010). Thus the information on drug resistance or sensitivity trends in a geographic area is helpful to veterinarians in selection of appropriate drugs for empirical therapy.

\section{Materials and Methods}

Three hundred rectal swabs were collected from diarrheic lambs below the age group of 8-weeks irrespective of their sex and breed, for the isolation of Escherichia coli. Rectal swabs were collected aseptically and processed within 2 to 4 hours for the isolation and identification of Escherichia coli (Barrow and Felham, 1992).

For isolation of E. coli, MacConkey agar (MCA) and Eosin methylene blue agar (EMB) were used as differential and selective plating media. Afore mentioned faecal samples were initially screened on MCA. Pink colored colonies on MCA plates (Plate2) were considered to be lactose fermenting isolates. Two such pink colonies from each MCA plate were picked up and transferred to EMB agar plate. Colonies with greenish metallic sheen (Plate-3) on EMB agar plates were considered to be of E. coli. In all $256 E$. coli isolates obtained from the faecal samples were used for further study.

Serogrouping: Confirmed E. coli isolates were sent to National Salmonella and Escherichia Centre, Central Research Institute, Kasouli (Himachal Pradesh) for serotyping.
In-vitro sensitivity: The antimicrobial susceptibility test was performed using KibryBauer disk diffusion method on Muller Hinton agar (HiMedia-India). Isolates were tested for the following antibiotics; ciprofloxacin $(5 \mu \mathrm{g})$, chloramphenicol (30 $\mu \mathrm{g})$, tetracycline $(30 \mu \mathrm{g})$, ampicillin $(10 \mu \mathrm{g})$, oxacillin $(10 \mu \mathrm{g})$, enrofloxacin $(30 \mu \mathrm{g})$, neomycin $(10 \mu \mathrm{g}), \quad$ co-trimoxazole (Thrimethoprim- sulfmethoxazole) $(25 \mu \mathrm{g})$, trimethoprim $(30 \mu \mathrm{g})$, gentamycin $(10 \mu \mathrm{g})$, amoxicillin $(10 \mu \mathrm{g})$ and $(30 \mu \mathrm{g})$ cefmetazole (HiMedia- India). According to the width of the inhibitory zone, the pattern of drug sensitivity was determined as susceptible and resistant.

In-vivo clinical study: The clinical trials were designed on thirty lambs exhibiting the symptoms of diarrhea and dehydration that were divided into five groups (six animals each). Only those antibacterials were given which showed moderate to high sensitivity invitro pattern against $E$. coli isolates, which were readily available and economically feasible.

\section{Results and Discussion}

The cultural examination of faecal samples collected from diarrhoeic lambs, revealed presence of Escherichia coli in 256 fecal samples out of total 300 samples. All the $E$. coli isolates were sent to National Salmonella and Escherichia Centre Kasouli (Himachal Pradesh) for serotyping. Isolates of E. coli were typed for ' $\mathrm{O}$ ' antigen. Out of $109 \mathrm{E}$. coli isolates, 93 belonged to 34 different ' $O$ ' serogroups while, twelve were untypable, and four were rough isolates. The prevalence of serogroups O20 was highest (10.09\%) followed by $\mathrm{O} 11$ (8.25\%), O123, O84 and O22 (7.33\% each), O107 (5.50\%), O89 and O92 (3.66\% each), O69 and O5 (2.75\% each), O157, O15,O36, O159 and O60 (1.83\% each) while as, serogroups of O1, O17, O19, O12, 
O26, O153, O23, O132, O88, O4, O43, O9, O56, O2, O154, O69, O68, O102 and $\mathrm{O} 103$ were the least $(0.91 \%$ each). Serogroups O12, O84, O2, O19, O60, O26, O15, O103 and O22 reported in the present study were also reported by Butaev (1978) from lambs and Rathore et al., (2003) in animals and humans. Serogroups O43, O153, O157, O20, O107, $\mathrm{O} 26, \mathrm{O} 88, \mathrm{O} 26, \mathrm{O} 15$ and $\mathrm{O} 132$ were reported by Wani et al., (2003-04) from diarrhoeic lambs and calves in Kashmir. Serogroups viz. $\mathrm{O} 11, \mathrm{O} 22, \mathrm{O} 23, \mathrm{O} 26, \mathrm{O} 4, \mathrm{O} 132$ and $\mathrm{O} 103$ have been reported by Blanco et al., (1996) from diarrhoeic lamb. Cid et al., (2001) reported the association of $\mathrm{O} 20, \mathrm{O} 22$ and $\mathrm{O} 4$ serogroups with lamb diarrhea (Morris and Sojka, 1985).

The E. coli isolates were tested against eleven commonly used antibiotics. Of the major isolates, 61.33 per cent of the isolates were sensitive to gentamicin followed by ciprofloxacin (60\%), neomycin (54.6\%), whereas co-trimoxazole $(50.6 \%)$, cefmetazole $(53.4 \%)$, tetracycline $(48 \%)$ and enrofloxacin $(46.7 \%)$ were moderately sensitive. Penicillin and trimethoprim showed resistant against 88 per cent and 34.6 per cent isolates respectively; while as maximum numbers of isolates were resistant to oxacillin $(93.3 \%)$ and amoxicillin (84\%).

Here highest percentage of isolates were sensitive to gentamicin and ciprofloxacin, similar findings have been previously reported (Wani et al., 2003; Gulsun et al., 2005; Gazelle et al., 2012) and in partial agreement with Cid et al., (1996). Aminoglycosides, such as gentamicin are highly effective as they have a selective, rapid bactericidal action especially, on Gram negative bacilli. Two members of quinolone group (ciprofloxacin and enrofloxacin) were tested for their efficacy against isolated strains, with average sensitivity of 80-90 per cent, however ciprofloxacin was highly sensitive against most of the isolates. This might be due to fact that this antibiotic had not been extensively used in lambs against the disease from this place. The high sensitivity against neomycin was also reported in lambs (Blanco et al., 1996). High sensitivity of $E$. coli isolates may be due to the uncommon use of this antibiotic. Co-trimoxazole showed good sensitivity against $E$. coli isolates from diarrheic lambs and this finding is in agreement with earlier reports of (Edrington et al., 2009 and Purkayastha et al., 2010). Ccefmetazole, a second generation cephalosporin moderately sensitive was placed third in order of sensitivity (Orden et al., 1999) and (Hariharan et al., 2004). In the present study higher per cent of isolates were resistant to amoxicillin; similar findings have been reported (Saravanbava 1990). The resistance recorded against penicillin derivatives (amoxicillin and oxacillin) in the present study may be due to their extensive use. In-vitro drug sensitivity pattern indicated that most identified serotypes were highly sensitive to four antibacterials, viz. gentamicin, ciprofloxacin, neomycin and cotrimoxazole.

The treatment (in-vivo efficacy) of the clinical cases of colibacillosis in lambs was studied on four trail groups of six lambs each (Table 2). Therapeutic efficacy of four different antibacterials viz. ciprofloxacin, gentamicin, neomycin and co-trimoxazole was evaluated (which showed higher in-vitro sensitivity against E. coli isolates) against clinical colibacillosis in lambs. The efficacy of the drugs was assessed as per the rate and degree of recovery of clinical symptoms. Gentamicin and ciprofloxacin, at dose rate of $4 \mathrm{mg} / \mathrm{kg}$ body weight daily for five days, proved to be most effective drugs wherein, drugs helped in restoration of the disturbed haemato biochemical changes and abating clinical symptoms. 
Table.1 In-vitro drug sensitivity pattern of $E$. coli isolates

\begin{tabular}{|c|c|c|c|c|c|c|c|c|c|c|c|}
\hline \multirow{2}{*}{$\begin{array}{l}\text { S. } \\
\text { No. }\end{array}$} & \multirow{2}{*}{ Antimicrobials } & \multirow{2}{*}{ Symbol } & \multirow{2}{*}{$\begin{array}{l}\text { Disc } \\
\text { content }\end{array}$} & \multicolumn{2}{|c|}{$\begin{array}{l}\text { Highly } \\
\text { sensitive }\end{array}$} & \multicolumn{2}{|c|}{$\begin{array}{l}\text { Moderate } \\
\text { sensitive }\end{array}$} & \multicolumn{2}{|c|}{$\begin{array}{l}\text { Low } \\
\text { sensitive }\end{array}$} & \multicolumn{2}{|c|}{ Resistant } \\
\hline & & & & No. & $\%$ & No & $\%$ & No & $\%$ & No & $\%$ \\
\hline 1. & Amoxycillin & Ac & $300 \mathrm{mg}$ & - & - & - & - & 12 & 16 & 63 & 84 \\
\hline 2. & Ciprofloxacin & $\mathrm{Cf}$ & $10 \mathrm{mcg}$ & 45 & 60 & 27 & 36 & 2 & 2.7 & 1 & 1.3 \\
\hline 3. & Gentamicin & $\mathrm{G}$ & $10 \mathrm{mcg}$ & 46 & 61.3 & 25 & 33.6 & 2 & 2.7 & 2 & 2.7 \\
\hline 4. & Tetracycline & $\mathrm{T}$ & $30 \mathrm{mcg}$ & 26 & 34.6 & 36 & 48 & 11 & 14.6 & 2 & 2.7 \\
\hline 5. & Penicillin & $\mathrm{P}$ & 10 units & - & - & - & - & 66 & 88 & 9 & 12 \\
\hline 6. & Neomycin & $\mathrm{N}$ & $30 \mathrm{mcg}$ & 41 & 54.6 & 29 & 38.7 & 3 & 4 & 2 & 2.7 \\
\hline 7. & Enrofloxacin & En & $10 \mathrm{mcg}$ & 30 & 40 & 35 & 46.7 & 7 & 9.3 & 3 & 4 \\
\hline 8. & Trimethoprim & $\operatorname{Tr}$ & $5 \mathrm{mcg}$ & 14 & 18.6 & 26 & 34.6 & 18 & 24 & 17 & 22.7 \\
\hline 9. & Oxacillin & Ox & $1 \mathrm{mcg}$ & - & - & 3 & 4 & 2 & 2.7 & 70 & 93.3 \\
\hline 10. & Cefmetazole & $\mathrm{Cf}$ & $30 \mathrm{mcg}$ & 12 & 16 & 40 & 53.4 & 20 & 26.7 & 3 & 4 \\
\hline 11. & $\begin{array}{l}\text { Co-trimoxazole } \\
\text { (trimethoprim/sulphamethoxazole) }\end{array}$ & Co & $\begin{array}{l}1.25 / 23.75 \\
\mathrm{mcg}\end{array}$ & 38 & 50.6 & 32 & 42.7 & 3 & 4 & 2 & 2.7 \\
\hline
\end{tabular}

Table.2 Therapeutic trials (In-vivo) in clinical cases of colibacillosis in lambs

\begin{tabular}{|c|c|c|c|c|c|c|c|c|c|c|c|}
\hline Groups & $\begin{array}{l}\text { Name of the } \\
\text { antibiotic }\end{array}$ & Dose & $\begin{array}{l}\text { No. of } \\
\text { cases } \\
\text { treated }\end{array}$ & $\begin{array}{c}\text { Day } \\
\text { I }\end{array}$ & Day II & $\begin{array}{c}\text { Day } \\
\text { IV }\end{array}$ & $\begin{array}{c}\text { Day } \\
\text { VI }\end{array}$ & $\begin{array}{l}\text { No. of } \\
\text { cases } \\
\text { Cured }\end{array}$ & \%age & $\begin{array}{c}\text { No.of } \\
\text { cases } \\
\text { Delayed }\end{array}$ & $\%$ age \\
\hline $\mathrm{I}$ & Control Group & - & six & - & - & - & - & six & 100.00 & - & - \\
\hline II & Control Group & - & $\operatorname{six}$ & - & - & - & - & - & - & $\operatorname{six}$ & 100 \\
\hline III & $\begin{array}{l}\text { Ciprofloxacin } \\
\text { (ciprobid) }\end{array}$ & $\begin{array}{l}4 \mathrm{mg} / \mathrm{kg}(250 \mathrm{mg} \\
\text { tab-1/4 } 4^{\text {th }} \text { twice } \\
\text { daily) }\end{array}$ & six & + & + & +++ & ++++ & six & 100.00 & - & - \\
\hline IV & $\begin{array}{l}\text { Co-trimoxazole } \\
\text { (Biotrim) }\end{array}$ & $\begin{array}{ll}15-30 & \mathrm{mg} / \mathrm{kg} \\
\mathrm{BW} & \text { (Bolus } \\
1 / 10^{\text {th }} \text { orally) }\end{array}$ & six & + & ++ & ++ & +++ & four & 66.68 & two & 33.34 \\
\hline V & $\begin{array}{l}\text { Gentamicin } \\
\text { (Gentamicin } \\
\text { Sulphate) }\end{array}$ & $\begin{array}{l}4 \mathrm{mg} / \mathrm{kg} \quad 0.3 \mathrm{ml} \\
\mathrm{iv} / \mathrm{im} \\
\text { BID daily }\end{array}$ & six & + & ++ & +++ & ++++ & six & 100.00 & - & - \\
\hline IV & Neomycin & $\begin{array}{l}10 \mathrm{mg} / \mathrm{kg} \mathrm{BW} \\
\begin{array}{l}\text { (Bolus } \\
\text { oraly) }\end{array} \quad 1 / 12^{\text {th }}\end{array}$ & six & + & + & +++ & +++ & five & 83.35 & one & 16.66 \\
\hline
\end{tabular}

+ = Slightly improved; ++ = Improved; +++ = Recovery; ++++ = Complete recovery

Another group of lambs was treated with another conventional gut acting antibacterial neomycin, dosage of $10 \mathrm{mg} / \mathrm{kg}$ body weight for five days that confirmed 83.35 per cent efficacy in this study. The infected group of lambs treated with co-trimoxazole at the dose rate of $15-30 \mathrm{mg} / \mathrm{kg}$ body weight, registered 66.8 per cent efficacy in this study. Similar efficacy of antibacterials against $E$. coli diarrhea was reported by Sakia and Harashma (1985). Treatment regimen (in-vivo efficacy) used in four different groups of clinical cases of colibacillosis indicated gentamicin and ciprofloxacin most effective drugs followed by neomycin and co-trimoxazole corresponding with in-vitro study.

In conclusion, one hundred nine isolates of $E$. coli were identified, characterized and got serotyped. Ninety three serotypes belonged to 34 different ' $O$ ' serogroups. Prevalence of serogroups $\mathrm{O} 20$ and $\mathrm{O} 11$ was highest with per cent prevalence of 10.09 and 8.25 respectively. Isolation of $E$. coli serogroups 
especially O26, O23, O17, O157, O153, O2 and $\mathrm{O} 5$ was alarming because of their zoonotic importance. In-vitro drug sensitivity pattern indicated that most identified serotypes were highly sensitive to four antibacterials, viz. gentamicin, ciprofloxacin, neomycin and co- trimoxazole. The therapeutic efficacy of four highly sensitive in-vitro drugs was evaluated, viz. gentamicin, ciprofloxacin, neomycin and co-trimoxazole. Gentamicin at $4 \mathrm{mg} / \mathrm{kg}$ body weight and Ciprofloxacin at $4 \mathrm{mg} / \mathrm{kg}$ body weight were found 100 per cent effective at 144 hour post treatment. Neomycin at $10 \mathrm{mg} / \mathrm{kg}$ body weight was 83.35 per cent effective and cotrimoxazole at $15-30 \mathrm{mg} / \mathrm{kg}$ body weight was 66.8 per cent effective at 144 hour post treatment.

\section{Acknowledgement}

The authors are thankful to the Department of Veterinary Medicine, Faculty of Veterinary Sciences, SKUAST-K for providing the approval and funding to undertake the study.

\section{References}

Ahmed, A. 2009. Epidemiological studies on some causes of lamb mortality in Sokoto state. PhD. Thesis. Usmanu Danfodiyo University, Sokoto, pp. 198.

Ahmed, A., Egwu, G.O., Garba, H.S., and Magaji, A.A. 2010. Isolation, Characterization and Antibiotic Susceptibility Pattern of Escherichia coli from Diarrhoeic Lambs in Sokoto, Northwestern Nigeria. Nigerian Vet. J., 31(4): 271-74.

Barrow, G.I. and Felham, R.K.A. 1992. Cowan and steel's Manual for the identification of Medical Bacteria. II Edn. University Press, Cambridge.

Bauer, A.W., Kirby, M.M., Sherris, J.C. and Truck, M. 1966. Antibiotic susceptibility testing by standard single disc method. American J. Clin. Pathol., 45: 493.

Blanco, J., Cid, D., Blanco, E.J., Blanco, M., Ruiz-Santa, J.A. and Fuente, R. 1996. Serogroups, toxins and antibiotic resistance of Escherichia coli strains isolated from diarrhoeic lambs in Spain. Vet. Microbiol., 49: 209-17.

Cid, D., Piriz, S., Ruiz-Santa, J.A., Valle, J., Vadillo, S. and Fuente, R. 1996. In vitro susceptibility of Escherichia coli strains isolated from diarrhoeic lambs and goat kids to 14 antimicrobial agents. J. Vet. Pharmacol., 5: 397- 401.

Edrington, T.S., Long, M., Ross, T.T., Thomas, J.D., Callaway, T.R., Anderson, R.C., Craddock, F., Salisbury, M.W. and Nisbet, D.J. 2009. Prevalence and antimicrobial resistance profiles of Escherichia coli O157:H7 and Salmonella isolated from feedlot lambs. J. Food Protection, 72(8): 1713717.

Gulsun, S., Oguzoglu, N., Inan, A. and Ceran, N. 2005. The virulence factors and antibiotic sensitivities of Escherichia coli isolated from recurrent urinary tract infections. Saudi Med. J., 26(11): 17551758.

Gyles, C.L. 1994. Escherichia coli in domestic animals and Humans. Wallingford, UK: CAD.

Hariharan, H., Mada, C., Poole, D. and Page, R. 2004. Antibiotic resistance among enterotoxigenic Escherichia coli from piglets and calves with diarrhea. Canadian Vet. J., 45: 605-06.

Hassan, N. and Sheikh, G.N. 2013. Prevalence of colibacillsis disease in lambs in Kashmir valley. Indian $J$. Animal Sci., 83(8): 784-85.

Lior, H. 1996. Classification of Escherichia coli p31-71. In: C. L. Gyles (ed). Escherichia coli in domestic animals and humans. CAB international, Wallingford, United Kingdom. 
Nataro, J.P. and Kaper, J.B. 1998. Diarrhoeagenic Escherichia coli. Clin. Microbiol. Review, 11: 142-201.

Orden, J.A., Ruiz-Santa, J.A., Cid, D., Garcia, S., Sanz, R. and Fuente, R. 1998. Verotoxin-producing Escherichia coli (VTEC) and eae-positive non-VTEC STEC and EPEC in 30-day-old diarrhoeic calves. Vet. Microbiol., 63: 239-48.

Purkayastha, M., Khan, M.S.R., Alam, M., Siddique, M.P., Begum, F., Mondal, T. and Choudhury, S. 2010. Molecular Characterization and Antibiogram study of sheep Escherichia coli in comparison to Escherichia coli of cattle and chicken. Int. J. Biores., 1(1): 25-29.

Gazalle, S., Taku, A., Bhat, M., Kumar, B. and Badroo, G.A. 2012. Serogroup detection, antibiotic resistance patterns and virulence gene profile of Escherichia coli isolated from diarrheic sheep. Indian J. Animal Sci., 82(11):
1290-1292.

Sakia, T. and Harashima, M. 1985. Therapeutic of Triminol Powder (TA068) in colibacillosis diarrhoea in piglet. J. Japan Vet. Med. Assoc., 38(2): 93-97. Saravanbava, K., Venugopalan, A.T. and Balaprakassam, R.A. 1990. Enteropathogenic E. coli associated with neonatal calf diarrhoea. Cherion, 19: 29-34.

Schoenian, S. 2006. Diarrhoea (scours) in small ruminants. In: Small Ruminant Fact Sheet Series. University of Maryland Cooperative Extension. Pp.14.

Wani, S.A., Bhat, M.A., Munshi, Z.H., Qureshi, S. and Buchh, A.S. 2003. Isolation and in-vitro sensitivity pattern of pathogenic Escherichia coli from diarrheic lambs and calves. Indian $J$. Ani. Sci., 73(2): 168-170.

\section{How to cite this article:}

Hassan, N. and Sheikh, G.N. 2017. Isolation, Serotyping and In-vitro and In-vivo Antibacterial Sensitivity of Escherichia coli Strains Isolated from Diarrheic Lambs in Kashmir. Int.J.Curr.Microbiol.App.Sci. 6(2): 955-960. doi: http://dx.doi.org/10.20546/ijcmas.2017.602.107 